UNDERGRADUATE RESEARCH IN NATURAL AND CLINICAL SCIENCE AND TECHNOLOGY (URNCST) JOURNAL Read more URNCST Journal articles and submit your own today at: https://www.urncst.com

\title{
The Effect of Natural Therapies in Combination with Usual Care for Depression: A Narrative Review
}

\author{
Prabhjot K Chohan, MD (India), CCNM student [1]*, Adam Gratton MSc, ND [1] \\ [1] Canadian College of Naturopathic Medicine, Toronto, Ontario, Canada M2K1E2 \\ *Corresponding Author: pchohan@ndnet.ccnm.edu
}

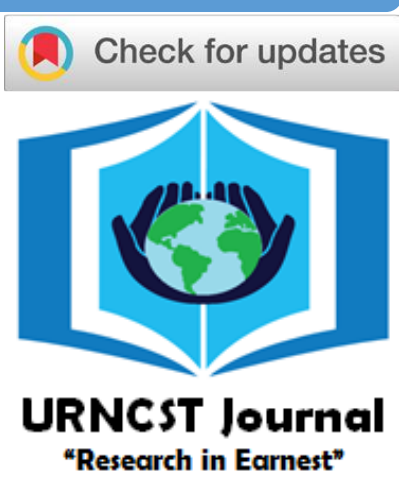

\begin{abstract}
Introduction: Major depressive disorder (MDD) is the most common and debilitating form of depression with a 12-month prevalence of $4.7 \%$ and a lifetime prevalence of $11.2 \%$ in Canada. Various classes of antidepressants are commonly used treatments for MDD; however, high failure rates occur due to adverse events and discontinuation of use. Non-drug and alternative interventions are commonly sought by people when drug treatment fails. The purpose of this investigation was to analyze the evidence on the effect of natural therapies in combination with pharmaceutical standard of care for the management of MDD

Methods: The following inclusion criteria were defined before conducting the literature search: 1) population of adults with major depressive disorder, 2) intervention of lavender, folic acid or acupuncture, combined with standard treatment, 3) comparison group of a placebo, standard treatment or natural therapy used alone, 4) changes to Hamilton Depression Rating Scale (HAM-D) as the primary outcome. PubMed, APA PsycARTICLES and Google scholar were used for the research. The articles were limited to randomized clinical trials (RCTs), and systematic reviews with meta-analyses. The different therapies were used as key words in the literature search.

Results: The literature search for 'lavender' yielded 214 studies, of which 3 RCTs met the criteria. 'Folic acid' yielded 680 studies of which 2 RCTs and 1 systematic review with meta-analysis met the criteria. 'Acupuncture' yielded 2240 studies of which 2 RCTs and 2 systematic reviews with meta-analyses met the criteria. Only the RCTs not summarized in the systematic reviews and meta-analyses were summarized in this review.

Discussion: All ten studies using natural interventions showed a statistically significant decrease in the mean score change versus comparison groups, however, the magnitude of the effect varied between the studies. Sample sizes were small and there was significant heterogeneity between studies.

Conclusion: Evidence suggests that natural therapies can be used adjunctively to the pharmaceutical care of MDD, however, the overall research quality is low and substantial heterogeneity exists between studies. Further, additional research using more rigorous methodologies and standardized interventions is needed.
\end{abstract}

Keywords: depression; major depressive disorder; integrative medicine; lavender; Lavandula; folate; folic acid; acupuncture

\section{Introduction}

Depression contributes significantly to the burden of disease throughout the world. It impacts health-related quality of life, functioning, and mortality due to intentional injury and the use of healthcare [1]. Among the types of depression, major depressive disorder (MDD) is the most common and debilitating form of depression [2] with a 12-month prevalence of $4.7 \%$ and a lifetime prevalence of $11.2 \%$ in Canada [3]. In 2017, MDD was the $11^{\text {th }}$ highest cause of global disability-adjusted life-years (DALYs) which correlates to overwhelming direct and indirect health services expenses [4].

Despite the high prevalence and economic burden, the pathophysiology of depression remains unclear, although several theories based on alteration of stress hormones, various neurotransmitters, neurocircuitry, neurotrophic factors, circadian rhythms [5,6] and altered gut microbiota have been proposed [7]. The risk of MDD is multifactorial with $30-40 \%$ contributed to genetic factors [8]. The latter are individual-specific environmental effects comprised mostly of adverse events in childhood and ongoing or recent stress due to interpersonal adversities, including childhood sexual abuse, other lifetime trauma, low social support, marital problems, and divorce $[9,10]$.

There is a broad range of pharmaceutical drugs available for the treatment of MDD. The use of antidepressants is effective in $20 \%-70 \%$ of patients treated for depression [11]. Failure to achieve desired outcomes is associated with adverse events, non-response, and withdrawal from the treatment $[2,12]$. The addition of effective natural therapies 
UNDERGRADUATE RESEARCH IN NATURAL AND CLINICAL SCIENCE AND TECHNOLOGY (URNCST) JOURNAL Read more URNCST Journal articles and submit your own today at: https://www.urncst.com

could facilitate dose reduction of the pharmaceuticals by decreasing their side effects [13] and/or lead to independent objective improvement [2]. The risk of discontinuation of treatment due to adverse events is usually less for natural therapies than for pharmaceuticals [2]. The Canadian Network for Mood and Anxiety Treatments (CANMAT) gives recommendations to the use of some natural therapies based on the availability of published evidence related to efficacy and safety [14]. Natural therapies such as St John's wort, omega 3 fatty acids, and exercise have level 1 evidence as adjunctive treatments in the management of MDD $[15,16,17]$. The data is well established for the Level 1 category evidence. On the other hand, the data is not fully established for natural therapies such as lavender, folate and acupuncture for use as adjunctive treatments in the treatment of MDD [14].

The purpose of this literature review was to analyze the evidence on the effect of natural therapies in combination with usual care as a treatment for MDD. This research is clinically relevant as clinicians working in different healthcare settings frequently encounter patients with depression. It is usually regarded that pharmacological treatments are better than natural therapies due to a larger evidence base and better-quality evidence for efficacy. However, a lack of data exists regarding interactions between natural therapies and conventional treatments for depression, as well as interactions between different natural therapies. This is of particular concern when patients do not reveal their use of natural therapies to clinicians. The focus of this literature review is to explore the effectiveness of three of these natural therapies; lavender, folic acid and acupuncture used in addition to pharmacological or usual care of MDD. No such review has been done in the literature that includes all three modalities. The three modalities were specifically chosen to describe the current level of evidence, establish their relevance in clinical use based on evidence in the literature and explore additional data related to them. This will guide the clinicians regarding the benefits of the specific therapy, and the specific factors that affect their use. Thus, this will increase the use of these natural therapies for better clinical outcomes.

The genus Lavandula belongs to the family Lamiaceae, which has more than 30 species [18]. Lavandula angustifolia (formerly $L$. vera or $L$. officinalis), popularly known as English lavender, has been used medicinally for its antidepressant and sedative properties [19]. The main constituents of lavender include linalyl acetate (30\%-55\%), linalool (20\%-35\%), beta-ocimene, cineol, camphor, sesquiterpene, caryophyllene oxide, tannin, rosmarinic acid derivatives, coumarine and flavonoids [20, 21]. Evidence suggests that lavender has an inhibitory effect on the central nervous system by affecting the activity of gamma amino butyric acid (GABA) neurons [22]. It also enhances the downstream effects of serotonin (5-HT1A) receptor activation similar to the effect of antidepressants [23].
Humans do not synthesize folic acid and rely on external sources for physiologic requirements [24]. The natural biologically active form of folic acid, found in sources such as green leafy vegetables, occurs mainly as 5-methyltetrahydrofolate (5-MTHF) [25]. The synthetic form of folic acid occurs as the completely oxidized pteroylmonoglutamic acid that has more stability than the natural form [26]. Folate acts as a cofactor in the pathways associated with the synthesis of various neurotransmitters involved in depression [27] such as dopamine, serotonin, and noradrenaline [28]. It acts as a methyl donor for the conversion of homocysteine to methionine, which leads to the production of S-adenosylmethionine (SAMe) [29]. Elevated homocysteine has been linked to mental health conditions, including depression [29].

Traditional acupuncture consists of the insertion of fine needles into various parts of the body along energy lines described by Traditional Chinese Medicine (TCM) [30]. Manual acupuncture involves the manual insertion of needles by a practitioner while electroacupuncture involves the application of a small amount of electric current through manually inserted acupuncture needles [31]. Neuroplasticity is disrupted in patients with depression stemming from changes induced by stress and other negative stimuli [32]. Acupuncture is involved in the modulation of neuroplasticity in the central nervous system [33] by raising the expression of neurotrophins such as brain-derived neurotrophic factor (BDNF) that increase synaptic transmission [33,34]. Acupuncture upregulates neurotransmitters such as norepinephrine, dopamine, and serotonin [33,35] and facilitates endogenous opioid mechanisms that modulate the pain pathways involved in neuroglial crosstalk and plasticity $[36,37]$. It reduces associated oxidative stress and apoptosis [36] and the action of inflammatory pathways, especially the toll-like receptor, and tumour necrosis factor (TNF) signaling pathways that activate the nociceptive neurons [ 37 , 38].

\section{Methods}

The following inclusion criteria were defined before conducting the literature search: 1) population of adults with MDD, 2) intervention of lavender, folic acid or acupuncture, combined with standard treatment, 3) comparison group of a placebo, standard treatment or natural therapy used alone, 4) changes to Hamilton Depression Rating Scale (HAM-D) as the primary outcome. All published articles from 1970 to April 2020 in English, searched from PubMed, APA PsycARTICLES and Google scholar were used for the research. The articles were limited to randomized clinical trials (RCTs), and systematic reviews with meta-analyses. The selected articles could also not be a part of a selected larger systemic review or meta-analysis used as a standalone reference. The articles were searched with the following keywords that included different treatments: 'depression', 'major depressive disorder', 'unipolar depression', 'lavender', 'lavandula', 'folate', 'folic acid', 'acupuncture'. 

UNDERGRADUATE RESEARCH IN NATURAL AND CLINICAL SCIENCE AND TECHNOLOGY (URNCST) JOURNAL
Read more URNCST Journal articles and submit your own today at: $\underline{\text { ttps://www.urncst.com }}$

Title and abstract screening were done by two reviewers based on the inclusion criteria. Studies that did not meet the inclusion criteria on full text were excluded. There were no disagreements in the selection of the articles.

\section{Results}

All ten studies using natural interventions showed a statistically significant decrease in the mean score change versus comparison groups. However, the magnitude of the effect varied between the studies. Sample sizes were small and there was significant heterogeneity between studies. A clinically significant outcome would be a reduction of 11 points in the HAM-D 17 scores and the magnitude of reduction observed in the studies summarized ranged between $4-15$ points [39]. The limited number of studies that met the inclusion criteria with supporting evidence were included in the review.

The literature search for lavender yielded 214 studies, of which 3 RCTs met the criteria. Lavender was given in the dose of $3-10 \mathrm{~g}$ as a decoction or 1:5 tincture in 50\% alcohol for $4-8$ weeks. The HAM-D scores were found to be decreased at different time points in the lavender studies, with a greater reduction in the combined drug and lavender groups than using either alone.

Folic acid yielded 680 studies of which 2 RCTs and 1 systematic review with meta-analysis met the criteria. Folic acid was given as $0.5 \mathrm{mg}-10 \mathrm{mg}$ of folate, $7.5 \mathrm{mg}$ to $15 \mathrm{mg}$ methyl folate or $1-5 \mathrm{mg}$ of folic acid for $1-3$ months. The reduction in the HAM-D score was greater in the combined drug and folic acid groups than using either of them alone. It was directly related to the dose of folic acid, and negatively correlated to the increase of blood folate level.

Acupuncture yielded 2240 studies of which 2 RCTs and 2 systematic reviews with meta-analyses met the criteria. Acupuncture was frequently administered in 30 minutes sessions, 3 times per week for $3-8$ weeks in the studies. The combination of acupuncture and drugs lead to a significant reduction in the HAM-D score than using either of them alone. The effect of electroacupuncture (EA) was greater than manual acupuncture (MA).

Table 1. The study methods and results for lavender, folic acid, and acupuncture studies

\begin{tabular}{|c|c|c|c|}
\hline Study & Natural intervention & Comparison & Results \\
\hline $\begin{array}{l}\text { Nikfarjam M, } \\
\text { Rakhshan R, Ghaderi } \\
H, 2017[40] \\
\mathrm{N}=120\end{array}$ & $\begin{array}{l}1.5 \mathrm{~g} \text { tea bag of } L . \\
\text { officinalis in a cup of } \\
\text { water as a decoction } \\
\text { every } 12 \text { hours for } 6 \\
\text { weeks }\end{array}$ & $\begin{array}{l}\text { 1. Placebo and } 37.5 \\
\mathrm{mg} / \text { day venlafaxine } \\
\text { 2. } 37.5 \mathrm{mg} / \text { day } \\
\text { venlafaxine }\end{array}$ & $\begin{array}{l}\text { A significant decrease }(\mathrm{p}=0.004) \text { in score in the } \\
\text { combined group versus using both treatments } \\
\text { alone. The depression scores of the groups } \\
\text { decreased over time and were significantly } \\
\text { different at various points of time }(\mathrm{p}<0.001) \text {. }\end{array}$ \\
\hline $\begin{array}{l}\text { Nikfarjam M et al., } \\
2013 \text { [41] } \\
\mathrm{N}=100\end{array}$ & $\begin{array}{l}2 \text { cups/day decoction of } \\
5 \mathrm{~g} \text { dried } L . \text { angustifolia } \\
\text { for } 8 \text { weeks }\end{array}$ & $\begin{array}{l}20 \mathrm{mg} \text { citalopram } \\
\text { BID }\end{array}$ & $\begin{array}{l}\text { A significant decrease }(\mathrm{p}<.01) \text { in score in the } \\
\text { combined group as compared to using selective } \\
\text { serotonin reuptake inhibitor }(\mathrm{SSRI}) \text { alone. After } 8 \\
\text { weeks, HAM-D was } 14.8 \pm 4 \text { and } 16.8 \pm 4.6 \\
\text { respectively in the groups }(\mathrm{p}<0.01) \text {. }\end{array}$ \\
\hline $\begin{array}{l}\text { Akhundzada et al., } \\
2003 \text { [42] } \\
\mathrm{N}=48\end{array}$ & $\begin{array}{l}60 \text { drops/day } L . \\
\text { angustifolia tincture for } \\
4 \text { weeks }\end{array}$ & $\begin{array}{l}\text { 1. Imipramine } 100 \\
\text { mg/day plus } \\
\text { placebo drops } \\
\text { 2. Lavandula } \\
\text { tincture (1:5 in } \\
50 \% \text { alcohol) } 60 \\
\text { drops/day plus } \\
\text { placebo tablet }\end{array}$ & $\begin{array}{l}\text { A combination of imipramine and } \\
\text { Lavandula tincture was more effective than } \\
\text { imipramine alone }(\mathrm{F}=20.83, \mathrm{df}=1 \\
\mathrm{P}<.0001)\end{array}$ \\
\hline $\begin{array}{l}\text { Morovati et al., } 2020 \\
\text { [43] } \\
\mathrm{N}=30\end{array}$ & $\begin{array}{l}1 \mathrm{mg} / \text { day folic acid } \\
\text { supplement for } 90 \text { days }\end{array}$ & $\begin{array}{l}20 \mathrm{mg} / \text { day } \\
\text { citalopram }\end{array}$ & $\begin{array}{l}\text { A decrease in HAM-D score was inversely } \\
\text { correlated to blood folate level. No significant } \\
\text { differences were found between the two groups in } \\
\text { the reduction of depression scores. }\end{array}$ \\
\hline $\begin{array}{l}\text { Roberts E, Carter B, } \\
\text { Young AH, } 2018 \text { [44] } \\
7 \text { RCTs } \\
\text { N=966 }\end{array}$ & $\begin{array}{l}\text { Folate: } .5 \mathrm{mg} \text { to } 10 \\
\text { mg/day or } \\
\text { Methylfolate: } 7.5 \mathrm{mg} \text { to } \\
15 \mathrm{mg} / \text { day for } 30-60 \\
\text { days }\end{array}$ & $\begin{array}{l}\text { 1. Placebo } \\
\text { 2. Folate } .5 \mathrm{mg} \text { to } \\
10 \mathrm{mg} / \text { day } 3 . \\
\text { Methylfolate } 7.5 \\
\mathrm{mg} \text { to } 15 \mathrm{mg} / \text { day }\end{array}$ & $\begin{array}{l}\text { Methylfolate at } 15 \mathrm{mg} / \mathrm{day} \text { and Folate }<5 \mathrm{mg} / \mathrm{day} \\
\text { with SSRIs causes a significant drop }(\mathrm{p}<.002, \\
\mathrm{p}<.001 \text {, respectively) in HAM-D score. } \\
\text { Methylfolate at } 15 \mathrm{mg} / \mathrm{d} \text { had effect size of }-0.74 \\
\text { ( } 95 \% \text { confidence interval }(\mathrm{CI}):-1.19,0.29 ; \\
\mathrm{p}=0.002) . \text { Folate at }<5 \mathrm{mg} \text { had effect size of }-0.57 \\
(95 \% \text { CI: }-0.91,0.23 ; \mathrm{p}<.001) \text {. }\end{array}$ \\
\hline
\end{tabular}


UNDERGRADUATE RESEARCH IN NATURAL AND CLINICAL SCIENCE AND TECHNOLOGY (URNCST) JOURNAL Read more URNCST Journal articles and submit your own today at: https://www.urncst.com

\begin{tabular}{|c|c|c|c|}
\hline $\begin{array}{l}\text { Venkatasubramanian } \\
\text { et al., } 2013 \text { [45] } \\
\mathrm{N}=42\end{array}$ & $\begin{array}{l}5 \mathrm{mg} / \text { day and } 1.5 \\
\mathrm{mg} / \mathrm{day} \\
\text { folic acid for } 6 \text { weeks }\end{array}$ & $\begin{array}{l}20 \mathrm{mg} / \text { day } \\
\text { fluoxetine }\end{array}$ & $\begin{array}{l}\text { HAM-D scores decreased more in the high folic } \\
\text { acid dose group but did not achieve statistical } \\
\text { significance }(\mathrm{p}=.15) \text {. }\end{array}$ \\
\hline $\begin{array}{l}\text { Zhao et al., } 2019 \text { [46] } \\
\mathrm{N}=477\end{array}$ & $\begin{array}{l}\text { Manual acupuncture or } \\
\text { electroacupuncture. The } \\
\text { acupuncture treatments } \\
\text { were done for } 30 \text { - } \\
\text { minute sessionwith } 3 \\
\text { sessions per week for } 6 \\
\text { weeks }\end{array}$ & SSRI alone group & $\begin{array}{l}\text { A significant improvement }(\mathrm{p}=.008) \text { in HAM-D } \\
\text { score in the combination group. The effect of } \\
\text { electroacupuncture was greater than manual } \\
\text { acupuncture. }\end{array}$ \\
\hline $\begin{array}{l}\text { Smith et al., } 2018[47] \\
11 \text { RCTs, N=653 }\end{array}$ & $\begin{array}{l}\text { Manual or } \\
\text { electroacupuncture for } \\
\text { 30- minute sessions 3-6 } \\
\text { times/week for 6-8 } \\
\text { weeks }\end{array}$ & Drug alone & $\begin{array}{l}\text { Manual acupuncture and drug combined were } \\
\text { more effective than drug alone }(\mathrm{p}=.0007) \\
\text { Electroacupuncture and drug more effective than } \\
\text { drug alone }(\mathrm{p}<.00001) \text {. The effect of acupuncture } \\
\text { in combination with antidepressants was better } \\
\text { when compared with medication alone (SMD - } \\
1.25,95 \% \text { CI }-1.83 \text { to }-0.67) \text {. }\end{array}$ \\
\hline $\begin{array}{l}\text { Chan et al., } 2015 \text { [48] } \\
13 \text { RCTs with } \mathrm{N}=1046\end{array}$ & $\begin{array}{l}\text { Manual acupuncture for } \\
\text { 30-minute sessions 3-6 } \\
\text { times/week for 6-8 } \\
\text { weeks }\end{array}$ & Drug alone & $\begin{array}{l}\text { A significant fall }(\mathrm{p}<.001) \text { in score in combined } \\
\text { group vs drug alone, EA>MA. The range of } \\
\text { response rates varied between } 18.2 \% \text { to } 100 \% \\
\text { (mean of } 50.83 \%) \text { with combination acupuncture } \\
\text { and antidepressant treatment. On the other hand, it } \\
\text { ranged from } 4.2 \% \text { to } 93.6 \% \text { (mean of } 50.83 \% \text { ) } \\
\text { with antidepressants alone. }\end{array}$ \\
\hline $\begin{array}{l}\text { Wang et al, } 2014[49] \\
N=76\end{array}$ & $\begin{array}{l}\text { Manual acupuncture } \\
\text { 30- minute } \\
\text { sessions, } 5 \text { days/week } \\
\text { for } 6 \text { weeks }\end{array}$ & SSRIs alone & $\begin{array}{l}\text { A significant reduction of } 17 \text { points }(\mathrm{p}<.05) \text { after } 6 \\
\text { weeks }(-1.83,95 \% \text { CI }-2.07 \text { to }-1.58) \text { in HAM-D } \\
\text { score in the combined group vs SSRI alone. }\end{array}$ \\
\hline
\end{tabular}

\section{Discussion \\ Lavender}

Evidence has shown that lavender can be combined with different antidepressants such as venlafaxine [40], citalopram [41], and imipramine [42] with significant improvement in outcome with possible synergistic or additive effects. Rapid therapeutic effects of Lavender can be accredited to uptake inhibition of noradrenaline, dopamine and serotonin [50]. This is similar to the mechanism of the antidepressant effect of Hypericum [50]. Lavender also produces an improvement in sleep in patients with MDD, possibly due to its inhibition of acetylcholine uptake in the neuromuscular junctions [51]. The combination of lavender and antidepressant use is associated with greater early antidepressant effects and reduces the adverse effects linked to the use of antidepressant medications [40]. However, the use of lavender as decoction and tincture increased the chances of non-compliance in the studies summarized in Table 1, indicating that soft gels or capsules are preferred. Soft gels or capsules are easily available and promote better patient adherence than decoction or tincture. Briefly, the combination of antidepressant and lavender was more effective in the management of depression than the antidepressant alone.

\section{Folic Acid}

Folate or methylfolate should not be offered as a monotherapy in patients with depression [44]. Folate at doses $<5 \mathrm{mg}$ /day or methylfolate at a dose of $15 \mathrm{mg} /$ day may be considered as an adjunct therapy to SSRIs in patients with MDD [44]. Doses of $1 \mathrm{mg} /$ day of folic acid produced no significant changes in the HAM-D scores although it raised the serum level of folate in the intervention group significantly [43]. The increase in serum folate was inversely correlated with a decrease in HAM-D score [43]. Earlier studies have also shown an inverse correlation between serum folate levels and symptoms of depression [52]. The relationship between dietary folate and depression severity significantly differs by race and ethnicity [43] and baseline levels of folic acid can affect the outcomes in patients without folic acid deficiency [45]. Gender differences in handling folic acid are another factor that might influence the outcomes as the response to folic acid supplementation is more pronounced in females than men [45]. A smaller response in men might be due to minimal changes in the levels of homocysteine [53]. Men might require increased doses of folic acid to lower homocysteine levels, hence boosting the antidepressant effect in men [53]. In terms of duration, the longer duration of supplementation with folic acid is associated with improved outcomes in patients with MDD [45,19]. Finally, the addition of folic acid to 
UNDERGRADUATE RESEARCH IN NATURAL AND CLINICAL SCIENCE AND TECHNOLOGY (URNCST) JOURNAL Read more URNCST Journal articles and submit your own today at: https://www.urncst.com

antidepressants augments the effect of antidepressants in the treatment of MDD. The variation in outcomes due to different factors affecting the levels of folic acid does lead to heterogeneity between the studies.

\section{Acupuncture}

The combination of acupuncture and antidepressants showed a reduction in the HAM-D score in the first week of treatment $[46,47,48,49]$. Additionally, the effects of acupuncture and antidepressant use were independent of each other and additive [48]. The quick onset of action is possibly associated with the rise in endogenous opioid peptide content [54]. Acupuncture in combination with a low dose of antidepressants was better tolerated than sham acupuncture with a high dose of antidepressants [55]. Groups receiving acupuncture in addition to medication showed decreased use of medication and improved aspects of quality of life with fewer side effects compared to the medication alone group [47]. Manual and electroacupuncture had a slightly different effect on the parameters of the HAM-D questionnaire. Electroacupuncture had a greater effect on the anxiety/somatization factor $(\mathrm{p}<0.001)$ and sleep disturbance factor $(p<0.01)$ than manual acupuncture [46]. To sum up, the studies showed that there is a significant benefit in using the combination of antidepressants and acupuncture in the management of depression as compared to using them alone with electroacupuncture having greater effect than manual acupuncture.

\section{Clinical Applications}

The evidence of the three interventions summarized suggests that have a significant advantage in lowering the depression scores in combination with pharmaceutical therapy. The magnitude of benefit for each natural therapy varied between the studies as indicated by the reduction in HAM-D scores in the combined drug and natural therapy groups versus those given the drugs alone. This could potentially encourage patient engagement and enhance treatment outcomes for patients with MDD.

Based on the evidence summarized, natural therapies appear to be safe when combined with antidepressant medications. However, there are a few side effects associated with their use. The adverse effects related to lavender include nausea, confusion [41], and headache [42] in patients with MDD. In the case of folic acid, an excess amount can mask the symptoms of anemia due to vitamin B12 deficiency leading to neurological complications [56,57]. Monitoring the level of minerals and vitamins in patients with MDD who receive antidepressants helps to optimize the outcome of supplementation with folic acid [43]. The adverse effects associated with acupuncture are few. Some of the minor reported adverse effects of acupuncture in patients with MDD include pain, bleeding, infection at the insertion site, headache, or pneumothorax in rare cases $[47,58,59]$.

Chohan et al. | URNCST Journal (2022): Volume 6, Issue 2

DOI Link: https://doi.org/10.26685/urncst.321

\section{Conclusions}

Most of the RCTs are double-blinded, and consistently positive results are seen for all interventions. However, small sample sizes, inconsistent dosing, minimal overlap between the acupuncture points, duration and use of antidepressants being different among studies were some of the limitations in the selected studies. A limited number of studies included in the review with rigorous methodologies are required to address lacunae in our current understanding of the efficacy of natural therapies as an adjunct to pharmacological treatment in patients with MDD.

All three natural therapies reviewed could be used as an adjunct to pharmaceutical care of MDD for a better therapeutic effect. This review can guide the clinicians to promote discussion with the patients for the inclusion of natural therapies in their treatment plan for MDD. It also provides a groundwork for studies for further investigation of the safety and efficacy of natural therapies.

\section{List of Abbreviations Used}

MDD: major depressive disorder

DALYs: disability-adjusted life-years

CANMAT: Canadian network for mood and anxiety

treatments

GABA: gamma amino butyric acid

5-MTHF: 5-methyltetrahydrofolate

SAMe: S-adenosylmethionine

TCM: traditional Chinese medicine

BDNF: brain-derived neurotrophic factor

TNF: tumour necrosis factor

HAM -D: Hamilton depression rating scale

RCTs: randomized clinical trials

EA: electroacupuncture

MA: manual acupuncture

SSRI: selective serotonin reuptake inhibitor

\section{Conflicts of Interest}

The authors declare that they have no conflicts of interest with respect to the research, authorship, and/or publication of this article.

\section{Ethics Approval and/or Participant Consent}

Given the literature review nature of this publication, ethics approval did not need to be obtained.

\section{Authors' Contributions}

PKC: developed the research strategy, collected and analyzed the data, drafted the manuscript, and gave final approval of the version to be published.

AG critically reviewed the research strategy and data analysis and gave final approval of the version to be published. 
UNDERGRADUATE RESEARCH IN NATURAL AND CLINICAL SCIENCE AND TECHNOLOGY (URNCST) JOURNAL Read more URNCST Journal articles and submit your own today at: https://www.urncst.com

\section{Acknowledgements}

The review paper was presented as a poster at the Research Day, March 2021 of the Canadian College of Naturopathic Medicine (CCNM) and the abstract was published in the URNCST Journal. We thank the Research department at CCNM for the updates and guidance in the process of publication.

\section{Funding}

This study was not funded.

\section{References}

[1] Steensma C, Loukine L, Orpana H, McRae L, Vachon J, Mo F, Boileau-Falardeau M, Reid C, Choi

BC. Describing the population health burden of depression: Health-adjusted life expectancy by depression status in Canada. Health Promotion and Chronic Disease Prevention in Canada. 2016 Oct;36(10):205-213. https://doi.org/10.24095/hpcdp.36.10.01

[2] Gartlehner G, Wagner G, Matyas N, Titscher V Greimel J, Lux L, Bradley N Gaynes NB Viswanathan M, Patel S, Lohr NK. Pharmacological and non-pharmacological treatments for major depressive disorder: Review of systematic reviews. British Medical Journal Open. 2017;7(6):014912. http://doi.org/10.1136/bmjopen-2016-014912

[3] Knoll AD, MacLennan RN. Prevalence and correlates of depression in Canada: Findings from the Canadian community health survey. Canadian Psychology. 2017 May; 58(2):116-123. https://doi.org/10.1037/cap0000103

[4] GBD 2017 DALYs and HALE Collaborators. Global, regional, and national disability-adjusted life-years (DALYs) for 359 diseases and injuries and healthy life expectancy (HALE) for 195 countries and territories, 1990-2017: A systematic analysis for the Global Burden of Disease Study 2017. Lancet. 2018;392(10159):1859-1922. https://doi.org/10.1016/s0140-6736(18)32335-3

[5] Hasler G. Pathophysiology of depression: Do we have any solid evidence of interest to clinicians? World Psychiatry. 2010;9(3):155-161. https://doi.org/10.1002/j.2051-5545.2010.tb00298.x

[6] Thompson SM, Kallarackal AJ, Kvarta MD, Van Dyke AM, LeGates TA, Cai X. An excitatory synapse hypothesis of depression. Trends in Neurosciences. 2015;38(5):279-294. https://doi.org/10.1016/j.tins.2015.03.003
[7] Fontana A, Manchia M, Panebianco C, Paribello P, Arzedi C, Cossu E, Garzilli M, Montis MA, Mura A, Pisanu C, Congiu D, Copetti M, Pinna F, Carpiniello B, Squassina A, Pazienza V. Exploring the role of gut microbiota in major depressive disorder and in treatment resistance to antidepressants. Biomedicines. 2020 Aug;8(9):311. https://doi.org/10.3390/biomedicines8090311

[8] Penner-Goeke S, Binder EB. Epigenetics and depression. Dialogues in Clinical Neurosciences. 2019 Dec;21(4):397-405. https://doi.org/10.31887/DCNS.2019.21.4/ebinder

[9] Raison CL, Miller AH. Pathogen-host defense in the evolution of depression: Insights into epidemiology, genetics, bioregional differences, and female preponderance. Neuropsychopharmacology. 2017 Jan;42(1):5-27. https://doi.org/10.1038/npp.2016.194

[10] Kendler KS, Gardner CO, Prescott CA. Toward a comprehensive developmental model for major depression in men. American Journal of Psychiatry. 2006 Jan;163(1):115. https://doi.org/10.1176/appi.ajp.163.1.115.

[11] Blackburn TP. Depressive disorders: Treatment failures and poor prognosis over the last 50 years. Pharmacology Research \& Perspectives. 2019 May;7(3):00472. https://doi.org/10.1002/prp2.472

[12] Paris J. The mistreatment of major depressive disorder. The Canadian Journal of Psychiatry. 2014;59(3):148151. https://doi.org/10.1177\%2F070674371405900306

[13] Sarris J, Kavanagh JD, Byrne G. Adjuvant use of nutritional and herbal medicines with antidepressants, mood stabilizers and benzodiazepines. Journal of Psychiatric Research. 2010; 44 (1): 32-41. https://doi.org/10.1016/j.jpsychires.2009.06.003

[14] Ravindran AV, Balneaves LG, Faulkner G, Ortiz A, McIntosh D, Morehouse RL, Ravindran L, Yatham LN, Kennedy SH, Lam RW, MacQueen GM, Milev RV, Parikh SV. CANMAT depression work group. Canadian network for mood and anxiety treatments (CANMAT) 2016 clinical guidelines for the management of adults with major depressive disorder: Section 5 - Complementary and alternative medicine treatments. Canadian Journal of Psychiatry. 2016;61(9):576-87. https://doi.org/10.1177/0706743716660290

[15] Linde K, Berner MM, Kriston L. St John's wort for major depression. Cochrane Database of Systematic Reviews. 2008;(4). https://doi.org/10.1002/14651858.CD000448.pub3

[16] Appleton KM, Sallis HM, Perry R, Ness AR, Churchill R. Omega-3 fatty acids for depression in adults. Cochrane Database of Systematic Reviews. 2015;(11). https://doi.org/10.1002/14651858.CD004692.pub4 
UNDERGRADUATE RESEARCH IN NATURAL AND CLINICAL SCIENCE AND TECHNOLOGY (URNCST) JOURNAL

Read more URNCST Journal articles and submit your own today at: https://www.urncst.com

[17] Cooney GM, Dwan K, Greig CA, Lawlor DA, Rimer J, Waugh FR, McMurdo M, Mead GE. Exercise for depression. Cochrane Database of Systematic Reviews $2013 ;(9)$.

https://doi.org/10.1002/14651858.CD004366.pub6

[18] Cavanagh HM, Wilkinson JM. Biological activities of lavender essential oil. Phytotherapy Research. 2002 Jun;16(4):301-8. https://doi.org/10.1002/ptr.1103

[19] Koulivand PH, Khaleghi Ghadiri M, Gorji A. Lavender and the nervous system. Evidence Based Complementary and Alternate Medicine. 2013;2013:10. https://doi.org/10.1155/2013/681304

[20] Prashar A, Locke IC, Evans CS. Cytotoxicity of lavender oil and its major components to human skin cells. Cell Proliferation. 2004;37(3):221-9. http://doi.org/10.1111/j.1365-2184.2004.00307.x

[21] Woronuk G, Demissie Z, Rheault M, Mahmoud S. Biosynthesis and therapeutic properties of Lavandula essential oil constituents. Planta Medica. 2011 Jan;77(1):7-15. https://doi.org/10.1055/s-0030-1250136

[22] López V, Nielsen B, Solas M, Ramírez Maria J., Jäger Anna K. Exploring pharmacological mechanisms of lavender (Lavandula angustifolia) essential oil on central nervous system targets. Frontiers in Pharmacology. 2017 May;8:280. https://doi.org/10.3389/fphar.2017.00280

[23] Baldinger P, Höflich AS, Mitterhauser M, Andreas H, Rami-Mark C, Spies M, Wadsak W, Lanzenberger R, Siegfried K. Effects of Silexan on the serotonin-1A receptor and microstructure of the human brain: A randomized, placebo-controlled, double-blind, crossover study with molecular and structural neuroimaging. International Journal of Neuropsychopharmacology. 2014;18(4):063. https://doi.org/10.1093/ijnp/pyu063

[24] Thien KR, Blair JA, Leeming RJ, Cooke WT, Melikian V. Serum folates in man. Journal of Clinical Pathology. 1977 May;30(5):438-48. http://doi.org/10.1136/jcp.30.5.438

[25] Lucock M. Folic acid: Nutritional biochemistry, molecular biology, and role in disease processes. Molecular Genetics and Metabolism. 2000 Sep;71(12):121-38. https://doi.org/10.1006/mgme.2000.3027

[26] Pietrzik K, Bailey L, Shane B. Folic acid and L-5methyltetrahydrofolate: Comparison of clinical pharmacokinetics and pharmacodynamics. Clinical Pharmacokinetics. 2010 Aug;49(8):535-48. https://doi.org/10.2165/11532990-000000000-00000

[27] Barnett H, D’Cunha NM, Georgousopoulou EN, Mellor D, McKune A, Naumovski N. Effect of folate supplementation on inflammatory markers in individuals susceptible to depression: A systematic review. Exploratory Research and Hypothesis in Medicine. 2017;2(4):86. https://doi.org/10.14218/ERHM.2017.00025
[28] Taylor MJ, Carney S, Geddes J, Goodwin G. Folate for depressive disorders. Cochrane Database of Systematic Review. 2003;2003(2). https://doi.org/10.1002/14651858.CD003390

[29] Almeida OP, Ford AH, Flicker L. Systematic review, and meta-analysis of randomized placebo-controlled trials of folate and vitamin B12 for depression. International Psychogeriatrics. 2015;27(5):727-737. https://doi.org/10.1017/S1041610215000046

[30] Armour M, Smith CA, Wang LQ, Naidoo D, Yang GY, MacPherson H, Lee MS, Hay P. Acupuncture for depression: A systematic review and meta-analysis. Journal of Clinical Medicine. 2019 Jul;8(8):1140. https://doi.org/10.3390/jcm8081140

[31] Napadow V, Makris N, Liu J, Kettner N, Kwong K, Hui K. Effects of electroacupuncture versus manual acupuncture on the human brain as measured by MRI. Human Brain Mapping.2005;24:193-205. https://doi.org/10.1002/hbm.20081

[32] Liu W, Ge T, Leng Y, Pan Z, Fan J, Yang W, Cui R. The role of neural plasticity in depression: From hippocampus to prefrontal cortex. Neural Plasticity. 2017;11. https://doi.org/10.1155/2017/6871089

[33] Xiao LY, Wang XR, Yang Y, Yang JW, Cao Y, Ma SM, Li TR, Liu CZ. Applications of acupuncture therapy in modulating plasticity of central nervous system. Neuromodulation. 2018 Dec;21(8):762-776. https://doi.org/10.1111/ner.12724

[34] Yang T, Nie Z, Shu H, Kuang Y, Chen X, Cheng J, Yu $\mathrm{S}$, Liu $\mathrm{H}$. The role of BDNF on neural plasticity in depression. Frontiers in Cellular Neuroscience. 2020 Apr;14:82. https://doi.org/10.3389/fncel.2020.00082

[35]Zang SH, Zhou L. Development of research on mechanisms of acupuncture underling improvement of depression. Zhen Ci Yuan Jiu. 2021 Sep;46(9):804-8. https://doi.org/10.13702/j.10000607.200507.PMID:345 $\underline{58249}$

[36] Leung MC, Yip KK, Ho YS, Siu FK, Li WC, Garner B. Mechanisms underlying the effect of acupuncture on cognitive improvement: A systematic review of animal studies. Journal of Neuroimmune Pharmacology.

2014;9(4):492-507. https://doi.org/10.1007/s114810149550-4

[37] Lyu Z, Guo Y, Gong Y, Fan W, Dou B, Li N, Wang S, Xu Y, Liu Y, Chen B, Guo Y, Xu Z, Lin X. The role of neuroglial crosstalk and synaptic plasticity-mediated central sensitization in acupuncture analgesia. Neural Plasticity. 2021 Jan;2021:8881557. https://doi.org/10.1155/2021/8881557

[38] Wang Y, Jiang H, Meng H, Li J, Yang X, Zhao B, Sun $\mathrm{Y}$, Bao T. Antidepressant mechanism research of acupuncture: Insights from a genome-wide transcriptome analysis of frontal cortex in rats with chronic restraint stress. Evidence Based Complementary Alternate Medicine. 2017: 1676808. https://doi.org/10.1155/2017/1676808 
UNDERGRADUATE RESEARCH IN NATURAL AND CLINICAL SCIENCE AND TECHNOLOGY (URNCST) JOURNAL Read more URNCST Journal articles and submit your own today at: https://www.urncst.com

[39] Carrozzino D, Patierno C, Fava GA, Guidi J: The Hamilton rating scales for depression: A critical review of clinimetric properties of different versions. Psychotherapy and Psychosomatics. 2020;89:133-150. https://doi.org/10.1159/000506879

[40] Nikfarjam M, Rakhshan R, Ghaderi H. Comparison of effect of Lavandula officinalis and Venlafaxine in treating depression: A double blind clinical trial. Journal of Clinical and Diagnostic Research. 2017 Jul; 11(7). https://doi.org/10.7860/jcdr/2017/20657.10233

[41] Nikfarjam M, Parvin N, Assarzadegan N, Asghari S. The effects of Lavandula angustifolia Mill. infusion on depression in patients using Citalopram: A comparison study. Iran Red Crescent Medical Journal. 2013;15(8):734-9. https://doi.org/10.5812/ircmj.4173

[42] Akhondzadeh S, Kashani L, Fotouhi A, Jarvandi S, Mobaseri M, Moin M, Khani M, Jamshidi HA, Baghalian K, Taghizadeh M. Comparison of Lavandula angustifolia Mill. tincture and imipramine in the treatment of mild to moderate depression: A double-blind, randomized trial. Progress in Neuropsychopharmacology and Biological Psychiatry. 2003;27(1):123-7. https://doi.org/10.1016/S02785846(02)00342-1

[43] Morovati M, Morsali Y, Rezaee S, Pezeshki A, Esmaeilzadeh A, Ranjbar H, Islambulchilar M. Increase in the folate level can decrease the intensity of disorder in patients with depression who use citalopram: A randomized clinical trial. Research Square. 2020 Apr.(1). https://doi.org/10.21203/rs.3.rs18168/v1

[44] Roberts E, Carter B, Young AH. Caveat emptor: Folate in unipolar depressive illness, a systematic review and meta-analysis. Journal of Psychopharmacology. 2018;32(4):377-384.

https://doi.org/10.1177\%2F0269881118756060

[45] Venkatasubramanian R, Kumar CN, Pandey RS. A randomized double-blind comparison of fluoxetine augmentation by high and low dosage folic acid in patients with depressive episodes. Journal of Affective Disorders. 2013 Sep;150(2):644-8. https://doi.org/10.1016/j.jad.2013.02.029

[46]Zhao B, Li Z, Wang Y, Ma X, Wang X, Wang X, Liang Y, Yang X, Sun Y, Song M, Guo T, Bao T, Fei Y. Can acupuncture combined with SSRIs improve clinical symptoms and quality of life in patients with depression? Secondary outcomes of a pragmatic randomized controlled trial. Complementary Therapies in Medicine. 2019;45:295-302.

https://doi.org/10.1016/j.ctim.2019.03.015

[47] Smith CA, Armour M, Lee MS, Wang LQ, Hay PJ. Acupuncture for depression. Cochrane Database of Systematic Reviews. 2018 Mar 4;3(3). https://doi.org/10.1002/14651858.CD004046.pub4
[48] Chan YY, Lo WY, Yang SN, Chen YH, Lin GJ. The benefit of combined acupuncture and antidepressant medication for depression: A systematic review and meta-analysis. Journal of Affective Disorders. 2015;176:106-17. https://doi.org/10.1016/j.jad.2015.01.048

[49] Wang T, Wang L, Tao W, Chen L. Acupuncture combined with an antidepressant for patients with depression in hospital: A pragmatic randomised controlled trial. Acupuncture in Medicine. 2014;32(4): 308-12. https://doi.org/10.1136\%2Facupmed2013010469

[50] Ruedeberg C, Wiesmann UN, Brattstroem A, Honegger UE. Hypericum perforatum L. (St John's wort) extract Ze 117 inhibits dopamine re-uptake in rat striatal brain slices. An implication for use in smoking cessation treatment? Phytotherapy Research. 2010 Feb;24(2):249-51. https://doi.org/10.1002/ptr.2921

[51] Fißler M, Quante A. A case series on the use of lavendula oil capsules in patients suffering from major depressive disorder and symptoms of psychomotor agitation, insomnia, and anxiety. Complementary Therapies in Medicine. 2014 Feb;22(1):63-9. https://doi.org/10.1016/j.ctim.2013.11.008

[52] Godfrey PS, Toone BK, Carney MW, Flynn TG, Bottiglieri T, Laundy M, Chanarin I, Reynolds EH. Enhancement of recovery from psychiatric illness by methylfolate. Lancet. 1990;336(8712):392-5. https://doi.org/10.1016/0140-6736(90)91942-4

[53] Coppen A, Bailey J. Enhancement of the antidepressant action of fluoxetine by folic acid: A randomised, placebo-controlled trial. Journal of Affective Disorders. 2000 Nov;60(2):121- 30. https://doi.org/10.1016/S0165-0327(00)00153-1

[54] Zhang J, Chen J, Chen J, Li X, Lai X, Zhang S, Wang S. Early filiform needle acupuncture for poststroke depression: A meta-analysis of 17 randomized controlled clinical trials. Neural Regeneration Research. 2014;9(7):773-84. http://doi.org/10.4103/1673-5374.131590

[55] Zhang JW, Yang BX, Liang BL. Combination of acupuncture and fluoxetine for depression: A randomized, double-blind, sham-controlled trial. Journal of Alternative and Complementary Medicine. 2009; 15(8):837-844. https://doi.org/10.1089/acm.2008.0607

[56] Elmore CL, Wu X, Leclerc D, Watson ED, Bottiglieri T, Krupenko NI, Krupenko SA, Cross JC, Rozen R, Gravel RA, Matthews RG. Metabolic derangement of methionine and folate metabolism in mice deficient in methionine synthase reductase. Molecular Genetics and Metabolism. 2007;91:85-97. https://doi.org/10.1016/j.ymgme.2007.02.001

[57] Stover PJ. Physiology of folate and vitamin B12 in health and disease. Nutrition Reviews. 2004 Jun;62:S3-12. https://doi.org/10.1111/j.17534887.2004.tb00070.x 
UNDERGRADUATE RESEARCH IN NATURAL AND CLINICAL SCIENCE AND TECHNOLOGY (URNCST) JOURNAL Read more URNCST Journal articles and submit your own today at: https://www.urncst.com

[58] White A. A cumulative review of the range and incidence of significant adverse events associated with acupuncture. Acupuncture in Medicine.2004;22(3):122-33. https://doi.org/10.1136\%2Faim.22.3.122
[59] Xu S, Wang L, Cooper E, Zhang M, Manheimer E, Berman B, Yong XS, Lao L. Adverse events of acupuncture: A systematic review of case reports. Evidence Based Complementary and Alternative Medicine. 2013(12):581203. http://doi.org/10.1155/2013/581203

\section{Article Information}

Managing Editor: Jeremy Y. Ng

Peer Reviewers: Pallavi Dutta, Bi-ru Amy Yeung

Article Dates: Received Aug 31 21; Accepted Dec 09 21; Published Feb 0722

\section{Citation}

Please cite this article as follows:

Chohan PK, Gratton A. The effect of natural therapies in combination with usual care for depression: A narrative review.

URNCST Journal. 2022 Feb 07: 6(2). https://urncst.com/index.php/urncst/article/view/321

DOI Link: https://doi.org/10.26685/urncst.321

\section{Copyright}

(C) Prabhjot K Chohan, Adam Gratton. (2022). Published first in the Undergraduate Research in Natural and Clinical Science and Technology (URNCST) Journal. This is an open access article distributed under the terms of the Creative Commons Attribution License (https://creativecommons.org/licenses/by/4.0/), which permits unrestricted use, distribution, and reproduction in any medium, provided the original work, first published in the Undergraduate Research in Natural and Clinical Science and Technology (URNCST) Journal, is properly cited. The complete bibliographic information, a link to the original publication on http://www.urncst.com, as well as this copyright and license information must be included.
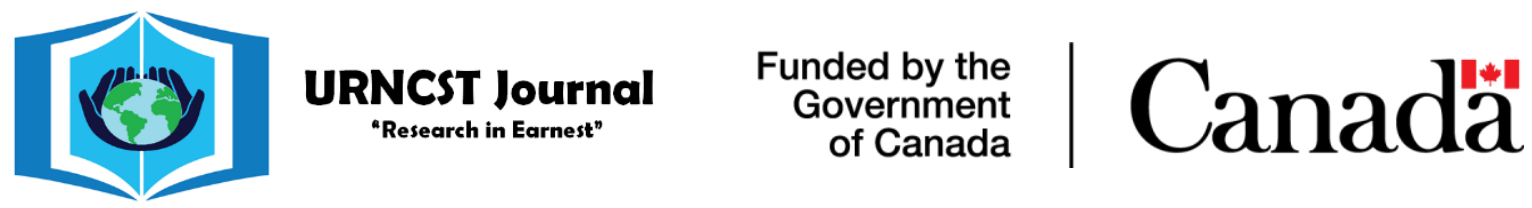

Do you research in earnest? Submit your next undergraduate research article to the URNCST Journal!

| Open Access | Peer-Reviewed | Rapid Turnaround Time | International |

| Broad and Multidisciplinary | Indexed | Innovative | Social Media Promoted |

Pre-submission inquiries? Send us an email at info@ urncst.com | Facebook, Twitter and LinkedIn: @URNCST

Submit YOUR manuscript today at https://www.urncst.com! 